\title{
連層耐震壁を有する $\mathrm{RC}$ 造 4 層建物縮小試験体の振動台実験による 架構の破壊形式と安全限界の評価
}

\author{
SHAKE-TABLE TEST OF A 4-STORY FRAME-WALL RC STRUCTURE \\ TO INVESTIGATE THE COLLAPSE MECHANISM AND SAFETY LIMIT
}

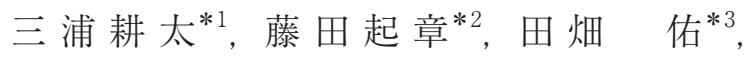 \\ 前田匡樹*4, Alex Shegay ${ }^{* 5}$, 米澤健 次*6 \\ Kota MIURA, Kisho FUJITA, Yu TABATA, \\ Masaki MAEDA, Alex SHEGAY and Kenji YONEZAWA
}

\begin{abstract}
To investigate an evaluation method of collapse mechanisms and the safety limit of $\mathrm{RC}$ buildings, a shake-table test of a $1 / 4$ scale model of a 4 story RC structure with shear walls was carried out. The specimen was designed to exhibit a frame-sway mechanism in both directions. In the test, the first-floor wall failed in flexure in the X-direction as designed; however, the first-floor wall in the Y-direction failed in shear, which did not match the design. Moreover, collapse mechanism and safety limit of the whole frame was discussed comparing the analytical result with the test result.
\end{abstract}

Keywords : Shake-table Test, RC Building; Safety Limit, Collapse Mechanism, Ultimate Deformation, Multi-story Shear Wall 振動台実験, $\mathrm{RC}$ 造建物, 安全限界, 破壊形式, 終局変形, 連層而震壁

\section{1. はじめに}

巨大地震発生時においては, 被災した建物の安全性を迅速に判断 し，効率的な復旧計画を立てることが重要である。そのためには， 建物の破壊形式や安全限界を正確に把握し，被災度を定量的に評価 する必要がある。 RC 造建物の被災度を定量的に評価する方法とし て, 日本建築防災協会の被災度区分判定基準 1)における, 耐震性能 残存率評価法があるが, 同手法では, 計算の単純化のため, 全ての 構造部材 (柱, 梁, 而震壁) の変形性能が同じであると仮定してい る。即ち, 各部材が同時に終局変形に達し, その時点が架構全体の 安全限界であると想定していることとなるが, 実構造物は様々な構 造部材から構成され，耐震壁と柱梁とでは剛性や変形性能が大きく 異なるため, 耐震壁の損傷が先行し, 柱梁よりも先に終局変形に達 することが予想される。そのため, 架構全体の安全限界点や破壊形 式（耐震壁が支配的となるか柱梁が支配的となるか）は，耐震壁と 柱梁の構成割合 (応力の負担比率) 等によって変わると考えられる。

一方, 筆者らによる既往の研究 2)では, 部材の変形性能等の違い を考慮して, 耐震性能残存率を評価する手法が提案されている。ま た，文献 3)では，変形性能の異なる複数の柱を有する架構の安全限
界の評価法が示されているが，これらの手法は，主に，純ラーメン 建物を対象としたものとなっている。

そこで, 筆者らは, 変形性能の異なる複数種類の部材（耐震壁と 柱梁）からなる建物において, 文献 3)の考えに従って, 架構の破壊 形式と安全限界を評価する手法を新たに提案した 4)。しかしながら, $\mathrm{RC}$ 造の耐震壁付ラーメン建物を対象とした過去の振動台実験 5),6) において, 架構の破壊形式や安全限界を判断するに至るまで, 即ち, 架構が崩壊に近い状態に達するまで加振を行った事例はほとんどな く, 提案手法の妥当性については, これまで具体的な検証が行われ ていなかった。また, 崩壊近くまで加振を行った事例 7においても, 架構の崩壊メカニズムは，主に，特定層の壁がせん断破壊するよう な層崩壊型が対象となっており, 曲げ降伏型全体崩壊形架構の崩壞 過程や安全限界については, 特に, 知見が不足していると言える。

そこで, 本研究では, 曲げ降伏型全体崩壊形の架構として設計し た，連層耐震壁を有する $\mathrm{RC}$ 造 4 層建物縮小試験体の振動台実験を 行い，架構が崩壊に至る過程を明らかにするとともに，文献 4)にお ける提案手法（架構の破壊形式と安全限界の評価法）の妥当性の検 証を行った。
*1 大林組技術研究所 研究員 $\cdot$ 修士 (工学)

$* 2$ 東北大学大学院工学研究科 大学院生

*3 久米設計 修士 (工学) (元東北大学大学院工学研究科 大学院生)

*4 東北大学大学院工学研究科 教授・博士 (工学)

*5 東北大学大学院工学研究科 学術研究員 $\cdot$ Ph.D.

*6 大林組技術研究所 主席技師・博士 (工学)
Researcher, Technical Research Institute, Obayashi Corporation, M.Eng.

Grad. Student, Graduate School of Eng., Tohoku Univ.

KUME SEKKEI Co., Ltd., M.Eng.

(Former Grad. Student, Graduate School of Eng., Tohoku Univ.)

Prof., Graduate School of Eng., Tohoku Univ., Ph.D.

Research Fellow, Graduate School of Eng., Tohoku Univ., Ph.D.

Senior Engineer, Technical Research Institute, Obayashi Corporation, Ph.D. 


\section{2. 解析結果に基づく架構の破壊形式と安全限界の評価方法}

\section{1 保有耐震性能指標の算定方法}

本研究において重要な概念となる, 保有耐震性能指標の概念と算 定方法を Fig. 1 及び以下に示寸。本会「鉄筋コンクリート造建物の 耐震性能評価指針 (案)」8)において, 保有耐震性能指標は, 限界地 震動（応答がある点に達する地震の大きさ）の基準地震動（想定さ れる地震の大きさで, 本研究では建設省告示 1457 号に規定される 第 2 種地盤の応答スペクトルの大きさ（1200gal） とする）に対す る比率として定義されており, 建物の耐震性能を定量的に評価寸る 指標として用いられている。等価線形化法を用いて保有耐震性能指 標を求める場合, 限界地震動は, 荷重増分解析結果の層せん断力一 層間変形角関係を 1 自由度系に縮約した代表変位一応答加速度関係 (性能曲線) 上のある点を通るスペクトルの大きさとして定義され る。ここで, 限界地震動は, 建物が弾性の場合に応答がある限界点 に達する地震動の大きさを表しており, 塑性化した場合には, 履歴 減衰による応答低減効果を別途考慮する必要がある。本報では, 文 献 9) と同様に, 基準地震動の応答スペクトルを, 履歴減衰の大きさ に応じた応答低減率 $\mathrm{F}_{\mathrm{h}}((1)$ 式) で低減し, 等価な弾性系の応答值と して基準地震動のスペクトルを求める。続いて, 求めた基準地震動 のスペクトルに対する限界地震動の比率として保有耐震性能指標 $\alpha$ を算定する。この手法では, 基準地震動の応答スペクトルを履歴減 衰の大きさに応じて低減し, 等価な弾性系における応答值と限界值 の比率（基準地震動と限界地震動のスペクトルの比率）をとること で，建物の保有耐震性能指標を定量的に評価していることとなる。

$$
\mathrm{F}_{\mathrm{h}}=1.5 /(1+10 \mathrm{~h})
$$

$\mathrm{h}=\Sigma\left(\mathrm{h}_{\mathrm{i}} \mathrm{W}_{\mathrm{i}}\right) / \Sigma \mathrm{W}_{\mathrm{i}}$

$\mathrm{h}_{\mathrm{i}}=0.05+0.25\left(1-1 / \sqrt{\mu_{\mathrm{i}}}\right) \quad\left(\mu_{\mathrm{i}} \leqq 1\right.$ の場合は $\left.\mathrm{h}_{\mathrm{i}}=0.05\right)$

$h_{i}, W_{i}, \mu_{i}$ : 保有耐震性能指標算定点における各部材の減衰定数, 歪 エネルギー，塑性率

\section{2 既往の研究及び本研究における評価法}

松川・前田らの研究 ${ }^{3}$ における安全限界評価法では, 性能曲線上 の各点において保有耐震性能指標 $\alpha$ を算定し, $\alpha$ が最大となる点を 架構の安全限界と定義している。ここで, 保有耐震性能指標は, 2.1 に示した手法と同様の考え（等価線形化法）に基づいて算定されて いる。文献 3)の手法は, 入力倍率を漸増させた動的解析に基づく方 法等, 他の評価手法と良好に対応寸ることが確認されている 3$), 10) 。$ また, Hao・前田らの研究 11)では, 文献 3)の手法を参考に, せん断 柱と曲げ柱が混在する架構の破壊形式と安全限界を, 略算的に求め る手法を提案している。しかしながら，これらの手法 ${ }^{3), 10), 11)} は$ はい゙ れも, 主に, 純ラーメン建物を対象としており, 変形性能の大きく 異なる複数種類の部材（例えば, 而震壁と柱梁）からなる建物にお いて, 架構全体の安全限界を評価すること, また, 安全限界点に基 づいて架構の破壊形式を評価することは想定していない。

そこで筆者らは, 変形性能の異なる複数種類の部材（耐震壁と柱 梁）からなる建物において, 文献 3)の考えに従って, 架構の破壊形 式と安全限界を評価する手法を新たに提案した ${ }^{4)}$ 。文献 4)における 提案手法（以下提案手法）の概要を Fig. 2 及び以下に示す。

（1）耐震壁と柱梁からなる建物では, 変形性能の小さい耐震壁が先 に破壊し, 架構の耐力低下が起こった後, 最終的に柱梁が破壊する と考えられる。耐震壁の耐力が破壊点で急激に低下して 0 になると

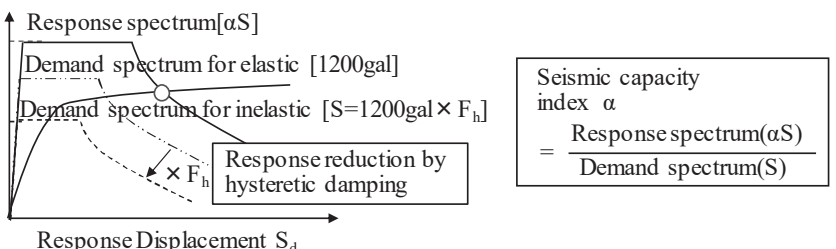

Fig. 1 Calculation method of seismic capacity index

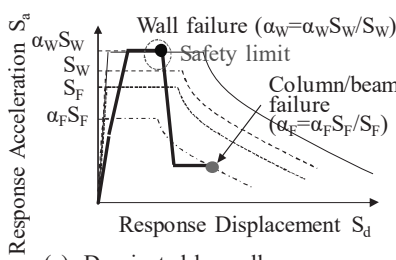

(a) Dominated by walls (X-direction of the specimen)

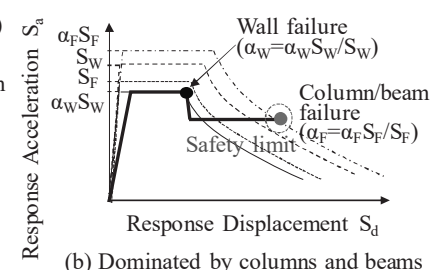

(b) Dominated by columns and beams (Y-direction of the specimen)

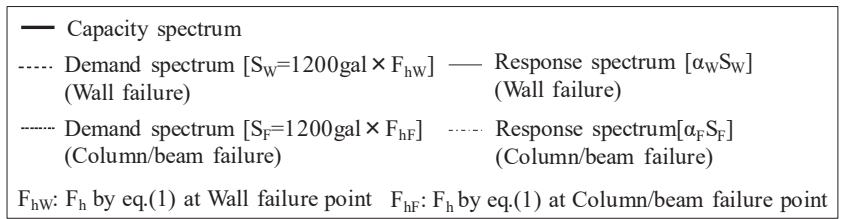

Fig. 2 Evaluation method of collapse mechanism and safety limit based on seismic capacity index

仮定した場合, 性能曲線は Fig. 2 に示寸形状となる。その場合, 保 有耐震性能指標 $\mathrm{a}$ の最大点は壁破壞点と柱梁破壊点のいずれかとな り，aの最大点を架構の安全限界とする文献 3)の考えに従うと，い ずれかの点が安全限界となる。そこで，耐震壁が破壊する点（壁が 終局変形に至る点) と柱梁が破壊する点(柱梁が終局変形に至る点) それぞれにおいて，2.1 の手法で保有耐震性能指標を計算し，壁破 壊点における值を $\alpha_{\mathrm{W}}$, 柱破壞点における值を $\alpha_{\mathrm{F}}$ とする。ここで, $\alpha_{\mathrm{W}}$ 及び $\alpha_{\mathrm{F}}$ は，壁破壊あるいは柱梁破壊によって決まる架構の耐震 性能を定量的に表寸值であり, 文献 8)の a と同様の意味合いを持つ。 尚, 後述するように, 柱梁破壊点における保有耐震性能指標 $\alpha_{\mathrm{F}}$ は, 壁の耐力を 0 とした（壁脚をピンとした）解析モデルに基づいて算 定することとしている。即ち，耐震壁が破壊した後の状態における 架構の耐震性能（1 回目の地震で耐震壁が破壊した後, 2 回目の地震 で柱梁が破壊に至る場合の 2 回目の地震の大きさ）を表している。 （2）保有耐震性能指標 $\alpha_{\mathrm{W}} ， \alpha_{\mathrm{F}}$ の大小関係から，試験体の破壊形式を 判定する。 $\alpha_{\mathrm{W}}>\alpha_{\mathrm{F}}$ の場合は, 壁破壊点が保有耐震性能指標最大点と なるため, 同点が架構全体の安全限界となる耐震壁支配型 (Fig. 2(a)), $\alpha_{\mathrm{F}}>\alpha_{\mathrm{W}}$ の場合は，柱梁破壊点が架構全体の安全限界となる柱梁支配 型（Fig. 2(b)）の架構であると判断出来る。尚, $\mathrm{aw}_{\mathrm{W}}=\mathrm{a}_{\mathrm{F}}$ の場合は, 架 構の安全限界変形を小さめ（安全側）に評価出来るよう，耐震壁破 壊点を安全限界点とし，耐震壁支配型の架構であると判断する。

本研究では, 提案方法の妥当性を検証するため, 連層耐震壁を有 する $\mathrm{RC}$ 造建物縮小試験体を設計し, 振動台実験を行った。振動台 実験の計画と結果を, 次章以降に示寸。

\section{3. 試験体計画 \\ 3.1 試験体概要}

試験体の全体図, 伏図, 軸組図を Fig. 3 に示寸。また, 部材断面 を Table 1 に示寸。試験体は, $\mathrm{RC}$ 造 4 層建物の $1 / 4$ スケールモデ ルであり, 長辺方向（X方向）と短辺方向（Y方向）共に, 連層耐 震壁を有する耐震壁付フレーム構造となっている。 


\section{2 試験体の設計方針及び詳細}

試験体の材料特性を Table 2, Table 3 に, 各部材（柱及び壁は 1 階) の曲げ強度, せ九断強度と終局変形角の計算值を Table 4 に示 す。ここで, 部材の曲げ強度は文献 12)の略算式, せん断強度は靭性 指針式 13) で求めた。鉄筋及びコンクリートの材料強度は, 材料試験 結果（Table 2, Table 3) を用いた。梁の曲げ強度の算定において は, 上引張時において有効幅内にあるスラブの上端筋を考慮した。 これは, スラブの下端筋は外周部では定着長の短い直線定着であり, 引張力の負担が期待できないこと, また, 中央部 (X2 通り梁 G 3 上) では通し配筋としており, 引張力は負担可能であるものの, 中立軸 からの距離が近く梁の曲げ強度への寄与は小さいと考えられるため である。尚, 上端笳は下引張時においては圧縮領域に位置すると考 えられるため, 曲げ強度の算定には考慮していない。これらの計算 条件は, スラブの配筋状態を反映したものであり, 実建物の設計に おいても一般的に用いられている。スラブの有効幅は, 当該梁方向 のスパンの 1/2 とした (Fig.3(b))。ただし, X 方向の梁 G1につい ては, スパンの $1 / 2$ とした場合に $\mathrm{Y} 1$ 通と $\mathrm{Y} 2$ 通の梁の有効幅となる 領域が重複するため, スパン中央までを各々の梁の有効幅とした。 スラブのせん断強度への寄与はないものとした。柱と壁の曲げ強度

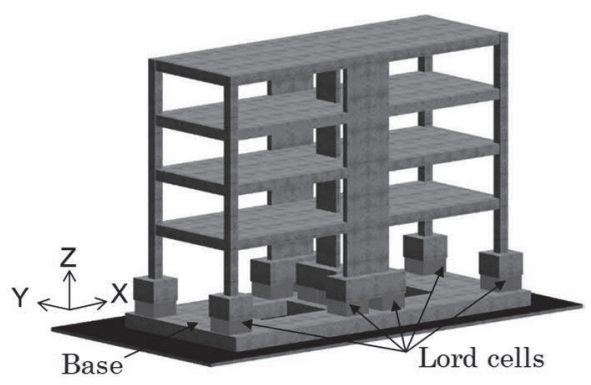

(a) Appearance of the test structure

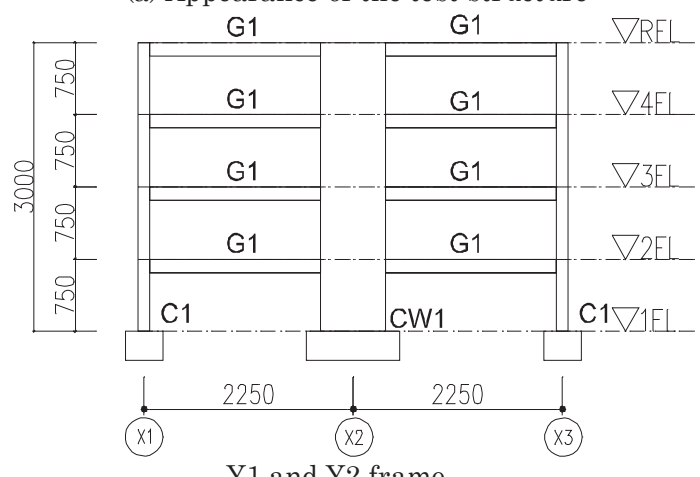

Y1 and Y2 frame

(c) Elevations of the test structure

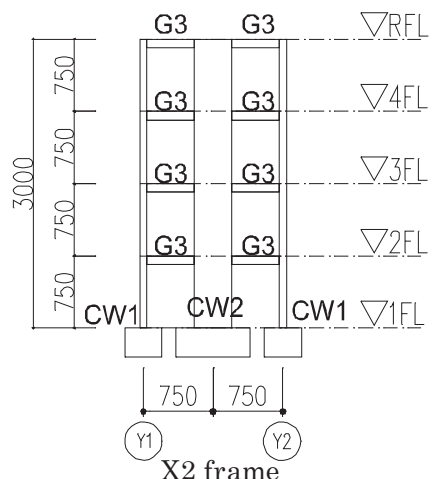

$\mathrm{X} 2$ frame
の計算においては, 変動軸力を考慮した。また, 終局変形角は, 文 献 13)に従って計算される部材のせん断強度＝曲げ強度となる点に おける変形角として求めた。ここで, 壁 CW2 の $\mathrm{X}$ 方向（面外方向） については, 中子筋の最大間隔が文献 13)の式の適用範囲外であっ たが，当該壁の面外方向の剛性は小さく，他の柱梁よりも先に終局 状態に達するとは考えにくいため, 終局変形角が十分大きいと仮定 した。また, 梁 G3については, せん断補強筋比が非常に大きく（約 $1.8 \%)$ ，他の柱梁よりも先に終局状態に達するとは考えにくいこと から，終局変形角が十分大きいと仮定した。尚，柱（壁の面外方向 を含む）及び梁の終局変形角が $1 / 25 \mathrm{rad}$ ～1/20rad. と一般的な值 ${ }^{14)}$ と比較して大きくなっているが，これは，耐震壁と柱梁の終局変形 角に差をつけることで，Fig. 2 に示した壁破壊点と柱破壊点の違い が明確に表れることを意図して設計したためである。

試験体は, 曲げ降伏型の全体崩壊形とし， 1 階の柱と壁の脚部と 各階の梁端に降伏ヒンジが形成されるように設計した。破壊形式の 違いが検討出来るよう, $\mathrm{X}$ 方向と $\mathrm{Y}$ 方向で而震壁の割合を変化させ た。 X 方向には，2 箇所に耐震壁を設け，耐震壁の破壊が支配的な 架構とした（Fig. 2(a)）。一方，Y方向では耐震壁を 1 箇所とし，柱 梁の破壊が支配的な（すなわち，耐震壁の破壊後にも耐震性を維持

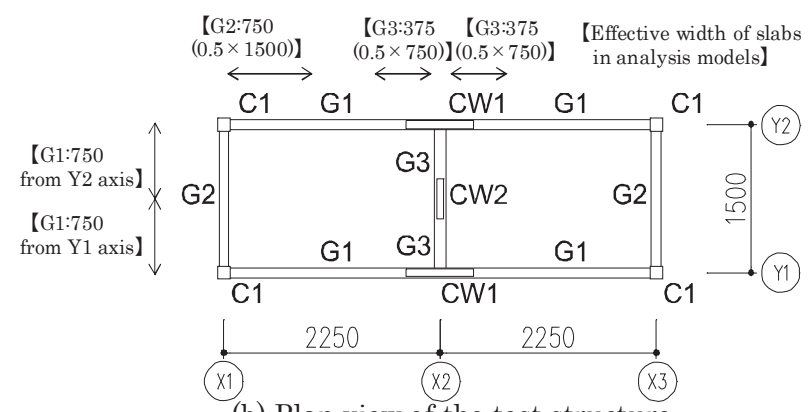

(b) Plan view of the test structure

Fig. 3 (a) General view; (b) plan view; (c) X-and Y-direction elevations of the test structure

Table 1 List of Members

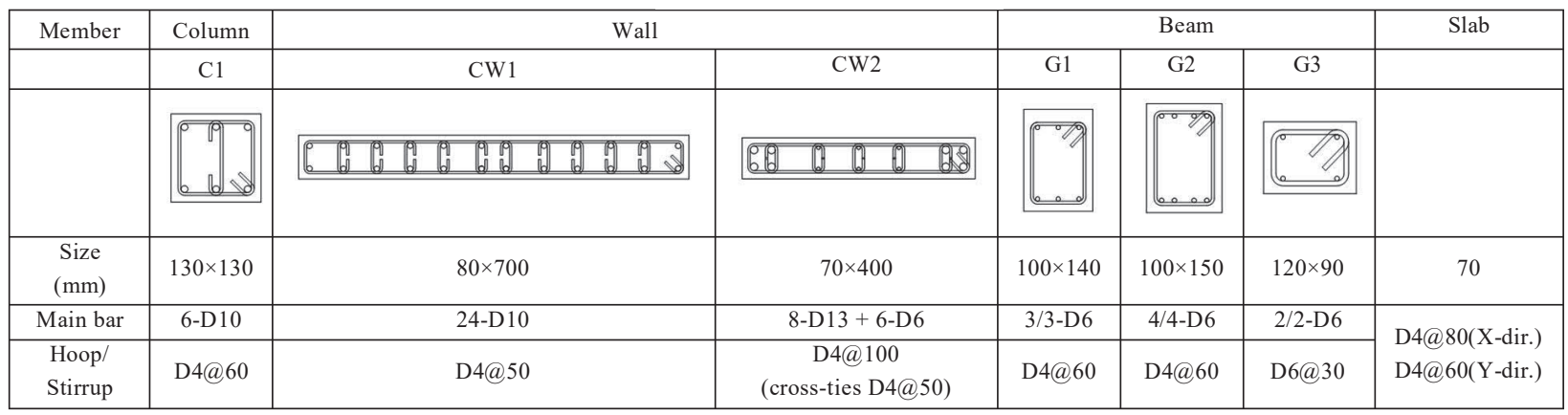


する）架構とした（Fig. 2(b)）。文献 1)の考えに従い, 架構全体の耐 力を, 全てのヒンジ発生位置の曲げ強度の合計值 $\Sigma \mathrm{M}_{\mathrm{u}}$, 耐震壁の負 担する耐力を, ヒンジの生じる 1 階壁脚の曲げ強度の合計值 $\Sigma_{\mathrm{w}} \mathrm{M}_{\mathrm{u}}$ として定義すると, 耐震壁の耐力の負担割合 $\left(\Sigma_{\mathrm{w}} \mathrm{M}_{\mathrm{u}} / \Sigma \mathrm{M}_{\mathrm{u}}\right)$ は, $\mathrm{X}$ 方 向で約 $60 \%, \mathrm{Y}$ 方向で約 $20 \%$ となる。尚, 層の水平耐力（層せん断 力）に対する耐震壁のせん断力の比率として, 耐震壁の耐力負担割 合を定義した場合, 境界梁の負担力が耐震壁の耐力に含まれてしま うため, 曲げ耐力に基づく定義を用いている。

試験体の各階床には鋼製鍾を設置し, 単位床面積あたりの重量が, 実大スケールと同様になるようにした。試験体と鋼製鍾の総重量は, 各階で約 $75 \mathrm{kN}$ (約 $11 \mathrm{kN} / \mathrm{m}^{2}$ ) である。床の四隅に設置した加速度 計で各階の加速度を, 1 階の柱及び壁の脚部と布基礎の間に設置し た分力計により, 1 階の柱と壁の負担せん断力を計測した。尚, 分 力計の計測值については, 校正試験（荷重/歪の係数算定試験）の 実施時と振動台実験時における応力状態（せん断力と軸力, モーメ ントの比率) や温度等の違いにより, 現時点では十分な計測精度が 得られていないため, 本論文中では記載を割愛する。層間変形は各 層に設置したレーザー変位計により計測した。各部材のヒンジ発生 想定位置には歪ゲージを貼付し，部材の降伏状況を確認した。

\section{4. 事前解析}

\section{1 解析モデル}

試験体の安全限界及び破壊形式の評価に用いる解析モデルは, 而 震壁及び柱梁を, 材端に曲げバネ, 中央にせん断バネと軸バネを持 つ線材に置換した立体フレームモデルとした。各部材の曲げバネは ひび割れ点及び降伏点を折れ点とするトリリニア型のモデルを用い た。せん断バネは, 柱・梁では弾性とし, 壁ではひび割れ点及び終 局強度点を折れ点とするトリリニア型のモデルとした。軸バネは全 ての部材で弾性とした。曲げバネのひび割れ強度と降伏強度は略算 式 12)で, せん断バネのひび割れ強度と終局強度は勒性指針式 13)で求 めた。曲げバネのひび割れ後の剛性低下率は, 菅野式 12)で求めた降 伏時剛性低下率に基づいて定めた。せん断バネのひび割れ後の剛性 低下率は文献 9)を参考に 0.2 とした。長期荷重は梁の分布荷重とし て与えた。水平外力を $\mathrm{Ai}$ 分布に基づいて設定し, 静的荷重増分解析 を行った。尚, 通常のモデル（耐震壁破壊前モデル, Fig.4(a)) に加 えて, 而震壁破壊後の架構の状態を想定し, 1 階の壁脚をピンとし たモデル（耐震壁破壊後モデル， Fig. 4(b)）の解析も行った。

\section{2 解析結果}

荷重増分解析結果における層せん断力一層間変形角関係を Fig. 5 に示す。図中に示されている壁破壊点は, いずれかの壁が Table 4 に示した終局変形角に達した点, 柱梁破壊点は, いずれかの柱ある いは梁が終局変形角に達した点として定義した。X方向では, 壁破 壊後の耐力の低下（耐震壁破壊前モデルと破壊後モデルの層せん断 力の差）が， $\mathrm{Y}$ 方向と比較して大きくなっていることがわかる。

\section{5. 解析結果に基づく架構の破壊形式と安全限界評価}

2 章に示した文献 4)の提案手法に従い, 解析結果に基づいて, 試 験体の破壊形式と安全限界点を評価した。解析結果に基づく性能曲 線と保有耐震性能指標の計算結果を Fig. 6 亿示す。ここで, 性能曲 線の計算においては, 壁破壊点までは耐震壁破壊前モデルを, 壁破
Table 2 Tested material properties of concrete (average of 1st-4th stories at the day of the test).

\begin{tabular}{|c|c|c|}
\hline Grade & $\begin{array}{c}\text { Compressive } \\
\text { strength }\left(\mathrm{N} / \mathrm{mm}^{2}\right)\end{array}$ & $\begin{array}{c}\text { Young's modulus } \\
\left(\mathrm{N} / \mathrm{mm}^{2}\right)\end{array}$ \\
\hline \hline Fc30 (early strength) & 53.1 & $2.97 \times 10^{4}$ \\
\hline
\end{tabular}

Table 3 Tested material properties of reinforcement

\begin{tabular}{|c|c|c|c|c|}
\hline $\begin{array}{c}\text { Diameter } \\
(\mathrm{mm})\end{array}$ & Grade & $\begin{array}{c}\text { Yield } \\
\text { strength } \\
\left(\mathrm{N} / \mathrm{mm}^{2}\right)\end{array}$ & $\begin{array}{c}\text { Maximum } \\
\text { strength } \\
\left(\mathrm{N} / \mathrm{mm}^{2}\right)\end{array}$ & $\begin{array}{c}\text { Young's } \\
\text { modulus } \\
\left(\mathrm{N} / \mathrm{mm}^{2}\right)\end{array}$ \\
\hline \hline 4 & SD295A & 402 & 533 & $1.90 \times 10^{5}$ \\
\hline 6 & SD345 & 419 & 613 & $1.97 \times 10^{5}$ \\
\hline 10 & SD345 & 339 & 562 & $1.93 \times 10^{5}$ \\
\hline 13 & SD390 & 407 & 602 & $1.95 \times 10^{5}$ \\
\hline
\end{tabular}

Table 4 Calculated flexural strength and ultimate deformation

\begin{tabular}{|c|c|c|c|c|c|c|c|c|c|c|}
\hline & & \multirow{2}{*}{\multicolumn{2}{|c|}{$\begin{array}{c}\text { Column } \\
\mathrm{Cl}\end{array}$}} & \multicolumn{4}{|c|}{ Wall } & \multicolumn{3}{|c|}{ Beam } \\
\hline & & & & \multicolumn{2}{|c|}{ CW1 } & \multicolumn{2}{|c|}{ CW2 } & \multirow{2}{*}{ G1 } & \multirow[t]{2}{*}{$\mathrm{G} 2$} & \multirow[t]{2}{*}{$\mathrm{G} 3$} \\
\hline & & X-dir. & Y-dir. & X-dir. & Y-dir. & X-dir. & Y-dir. & & & \\
\hline \multirow{2}{*}{$\begin{array}{l}\text { Flexural } \\
\text { strength } \\
(\mathrm{kNm})\end{array}$} & $\begin{array}{c}\text { Compression side } \\
\text { / Upper tension }\end{array}$ & 8.9 & 12.8 & \multirow{2}{*}{184.9} & 23.6 & \multirow{2}{*}{15.1} & \multirow{2}{*}{89.2} & 10.0 & 14.5 & 6.2 \\
\hline & $\begin{array}{l}\text { Tension side / } \\
\text { Lower tension }\end{array}$ & 5.1 & 6.3 & & 18.5 & & & 4.4 & 6.4 & 1.7 \\
\hline \multicolumn{2}{|c|}{ Shear strength $(\mathrm{kN})$} & 43.2 & 59.7 & 325.2 & 98.1 & 39.9 & 117.0 & 44.1 & 48.6 & 27.7 \\
\hline \multirow{2}{*}{$\begin{array}{l}\text { Ultimate } \\
\text { deformation } \\
\text { (rad.) }\end{array}$} & $\begin{array}{c}\text { Compression side } \\
\text { / Upper tension }\end{array}$ & 0.038 & 0.039 & \multirow{2}{*}{0.021} & 0.042 & \multirow{2}{*}{$※$} & \multirow{2}{*}{0.022} & 0.044 & 0.039 & $※$ \\
\hline & $\begin{array}{l}\text { Tension side / } \\
\text { Lower tension }\end{array}$ & 0.044 & 0.043 & & 0.044 & & & 0.050 & 0.047 & $※$ \\
\hline
\end{tabular}

※Estimated large enough

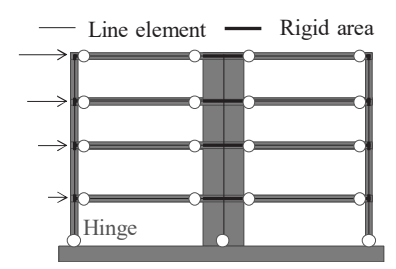

(a) Pre-wall failure model

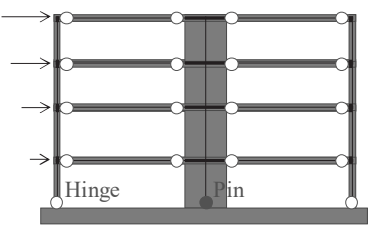

(b) Post-wall failure model Fig. 4 Models for pushover analysis

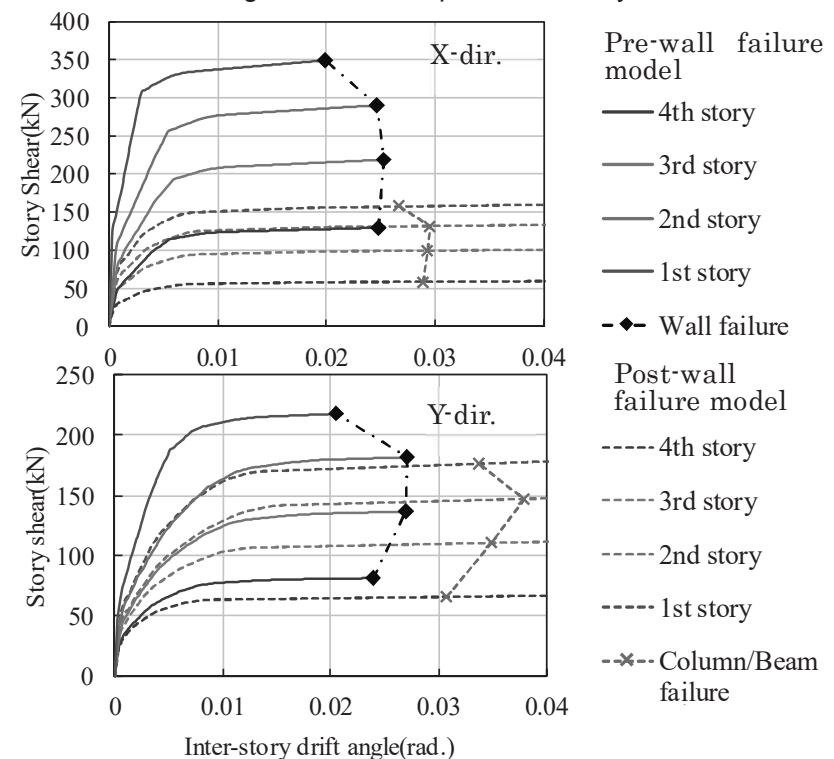

Fig. 5 Story shear- inter-story drift relationships by pushover analyses

壊点〜柱梁破壊点では，耐震壁破壊後モデルを用いている。即ち， 1 階壁脚の曲げ耐力は, 壁破壞点において急激に低下し 0 になると 仮定している。また，計算に用いるスペクトルは，実スケールの建 物用に設定されたものであるため, 同図中では, 性能曲線における 
変位 (横軸) の值を 4 倍にして計算している。2 章に示したように, 基準地震動の大きさは, 減衰定数の值に応じて低減されるため, 壁 破壊点と柱梁破壊点で異なる大きさとなっている。

保有耐震性能指標は, $\mathrm{X}$ 方向では $\alpha_{\mathrm{W}, \mathrm{X}}>\alpha_{\mathrm{F}, \mathrm{X}}, \mathrm{Y}$ 方向では $\alpha_{\mathrm{F}, \mathrm{Y}}>\alpha_{\mathrm{W}, \mathrm{Y}}$ となっている。即ち, $\mathrm{X}$ 方向は, 壁支配型の架構であり, 壁破壊点 が架構全体の安全限界となる。また, Y 方向は柱梁支配型の架構で あり，柱梁破壊点が架構の安全限界であると判断出来る。

\section{6. 振動台実験の入力地震波}

入力地震波は, 建設省告示 1457 号に規定される, 第 2 種地盤の 応答スペクトル（Fig. 7(c)に基準スペクトルとして示されているも の）に適合する人工地震波とし, 位相は, 1995 年の兵庫県南部地震 における JMA 神戸の位相 (X 方向は NS 位相, Y 方向は EW 位相) を用いた。入力波の時刻歴波形と加速度応答スペクトルを Fig. 7 に 示す。Fig. 7(c)には, 実験前後の試験体の固有周期を合わせて示し ている。ここで，入力波の時間軸は相似則に基づいて原波形の $1 / 2$ に縮小している。入力波の加速度応答スペクトルは, 試験体の保有 耐震性能指標と安全限界の評価に用いているスペクトル (Fig. 6)に 対応するものである。入力倍率を順次増加 (一部低減)させながら, 水平 2 方向の同時加振を合計 9 回行った。各加振の入力倍率につい ては, 後述の Table 5 を参照されたい。

\section{7. 振動台実験結果}

各加振における最大応答層間変形角と 1 層の最大応答層せん断力, 損傷経過を Table 5 に, 最終加振終了後の試験体の損傷状況を Fig. 8 に示す。各加振終了後 (Run7,8 を除く) において, 損傷観察を施 し, 各部材の損傷度の判定を行った。部材損傷度は, 被災度区分判 定基準 ${ }^{11}$ に従い, 損傷度 0 から V までの 6 段階で評価した。ここで, 損傷度 $\mathrm{V}$ は, 主筋の座屈やコアコンクリートの圧壊が生じ, 柱や壁 では，一見して水平方向や鉛直方向に残留変形が生じていることが わかる状態に該当する。

Run1 では, 耐震壁と一部の柱梁の端部に曲げひび割れが発生し た。Run3 では, 1 階の柱脚と X 方向の壁脚で主筋が降伏した。Run4 では, 1 階の Y 方向壁脚と 4 階の柱頭, 各階の梁端で主筋が降伏し, 架構が崩壊メカニズムに達した。1 階の Y 方向壁では主筋とほぼ同 時に, 横補強筋の降伏が確認された。Run5 では, 1 階の X 方向の 壁脚及び柱脚でコンクリートの剥落が生じた。また，Y方向 1 階の 壁では，せん断ひび割れが大きく開き，コンクリートの剥落も生じ た。Run5において, 試験体は, X方向と $\mathrm{Y}$ 方向の両方で, 概ね最 大耐力に達した。Run7 では, Y 方向の 1 階壁がせん断破壞し（損 傷度 V に達し，Fig. 8(d))，3.2 に示した設計時の想定（曲げ破壊） とは異なる結果となった。これは, スラブの影響により, 境界梁 G3 （Fig. 3 参照）の曲げ強度が想定よりも大きくなり，壁の反曲点位 置が下部に移動したためと考えられる。最終加振 (Run9) では Fig. 8(b)に示すように, 1 階の X 方向の壁脚部で, 主筋の座屈とコアコ ンクリートの圧壊が生じ, 曲げ破壞に至った。

各層の層せん断力－層間変形角及び（全ての加振の内の） 1 層の 層せん断力最大時における層せん断力分布（1 層が 1 となるように 基準化した值）をFig. 9 に示す。層せん断力は, 各階床に設置した 加速度計の計測值に層重量を乗じて求めた慣性力を最上階から当該

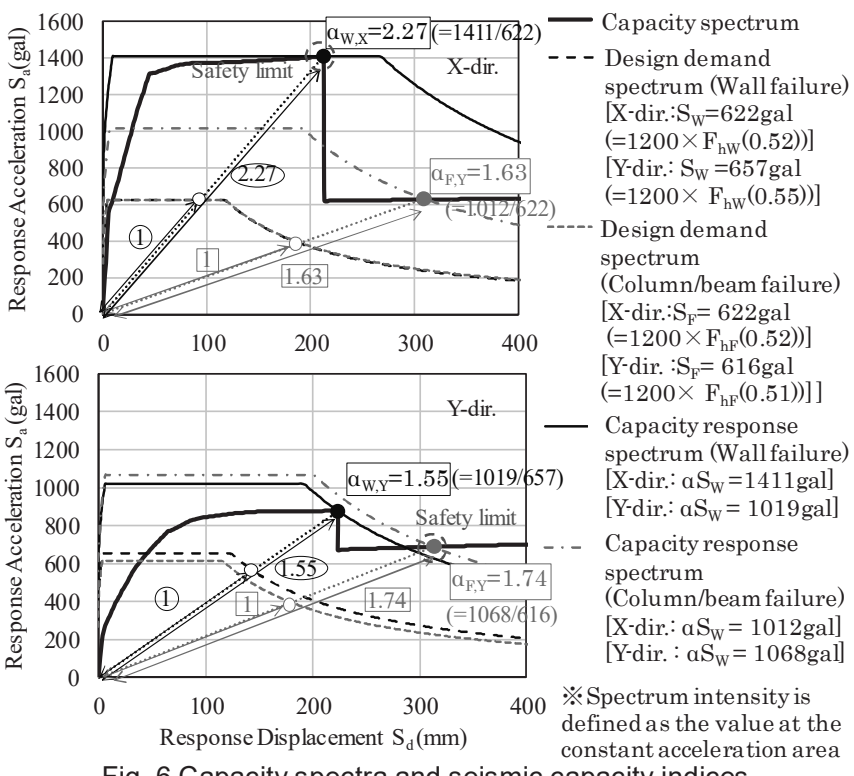

Fig. 6 Capacity spectra and seismic capacity indices

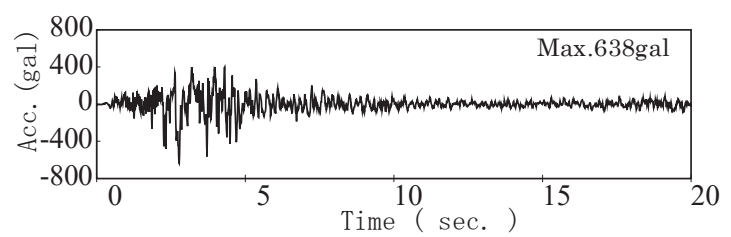

(a) Time history of X-direction wave (Kobe NS phase)

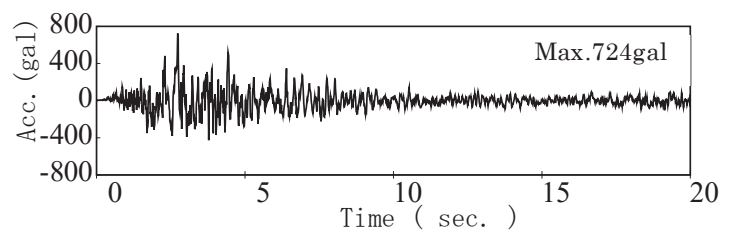

(b) Time history of Y-direction wave (Kobe EW phase)

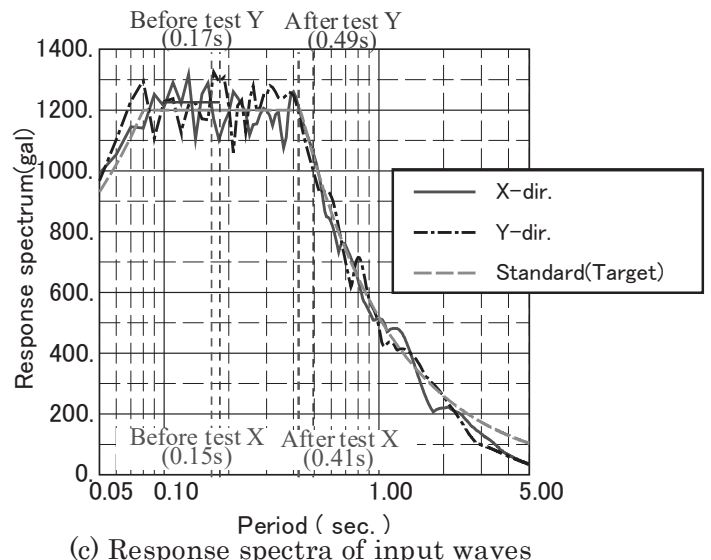

(c) Response spectra of input waves

Fig. 7 Time histories and response spectra of input waves

階まで累加することで算出した。この計算手法は文献 5),6),7)で用い られているものと同様であり, 算出される值は減衰力（粘性減衰） を含んだものとなる。Fig. 9(a)には, Fig. 5 の事前解析結果を, Fig. 9(b)には事前解析で用いた $\mathrm{Ai}$ 分布に基づく值を合わせて示してい る。事前解析においては，1 階壁脚の曲げ耐力は，壁破壊点におい て急激に低下し 0 になるとの仮定に基づいて算出している。試験体 の最大耐力は, 実験結果で解析結果よりも $\mathrm{X}$ 方向で $30 \%, \mathrm{Y}$ 方向で 35\%程度高くなった。この原因として, スラブ有効幅が解析モデル における想定（スパンの 0.5 倍）よりも大きくなっていることや， 
解析モデルでは考慮していないスラブの下端筇が梁の曲げ強度の上 昇に寄与していること等が考えられる。本試験体においては，鋼製 錘の荷重を負担する関係で，スラブが通常よりも厚くなっており， 梁せいとの差が小さいため, スラブの下端筋が梁の下引張の曲げ強 度に寄与しやすくなっていると言える。層せん断力分布は，4 層で 実験值がやや小さくなっているが，概水実験值と解析值（Ai 分布） が一致していた。

変形性能（耐力低下が生じはじめる形）は, $\mathrm{X}$ 方向, $\mathrm{Y}$ 方向と
もに, 解析結果よりも高い結果となった。特に, X 方向では, 最大 層間変形角が $1 / 18 \mathrm{rad}$ に達した最終加振においても, 耐力低下はほ とんど見られなかった。文献 13)に従って算定される部材の終局変 形角 (Table 4) は, 一般に安全側の值を与えるとされているが 13),14), 本実験においても同様の傾向が示されたと言える。また, 事前解析 で用いた, 壁が曲げ破壊後に曲げ耐力が急激に低下寸る（０になる） という考えは, 架構の構造性能を評価するにあたって, 過度に安全 側の仮定になる可能性がある。

Table 5 Outline of test result

\begin{tabular}{|c|c|c|c|c|c|c|c|}
\hline \multirow[b]{2}{*}{ Run } & \multicolumn{3}{|c|}{$\mathrm{X}$-direction } & \multicolumn{3}{|c|}{ Y-direction } & \multirow[b]{2}{*}{ Event } \\
\hline & $\begin{array}{c}\text { Magnifi } \\
\text {-cation }\end{array}$ & $\begin{array}{l}\mathrm{Q}_{1 \max } \\
(\mathrm{kN})^{*} \\
\end{array}$ & $\begin{array}{l}\mathrm{R}_{\max }(\mathrm{rad} .) \\
\text { [story] }^{* *}\end{array}$ & $\begin{array}{c}\text { Magnifi } \\
\text {-cation }\end{array}$ & $\begin{array}{l}\mathrm{Q}_{1 \max } \\
(\mathrm{kN})^{*}\end{array}$ & $\begin{array}{l}\mathrm{R}_{\max }(\mathrm{rad} .) \\
{[\text { story] }}\end{array}$ & \\
\hline 1 & $20 \%$ & 51.2 & $1 / 1384\left[2^{\text {nd }}\right]$ & $20 \%$ & 48.6 & $1 / 1475\left[2^{\text {nd }}\right]$ & Member cracking \\
\hline 2 & $80 \%$ & 167.0 & $1 / 320\left[2^{\text {nd }}\right]$ & $60 \%$ & 128.0 & $1 / 447\left[1^{\text {st }}\right]$ & \\
\hline 3 & $160 \%$ & 292.4 & $1 / 154\left[2^{\text {nd }}\right]$ & $100 \%$ & 195.1 & $1 / 210\left[2^{\text {nd }}\right]$ & 1st floor column and wall yielding \\
\hline 4 & $240 \%$ & 402.9 & $1 / 73\left[3^{\text {rd }}\right]$ & $150 \%$ & 290.2 & $1 / 77\left[2^{\text {nd }}\right]$ & Frame-sway mechanism reached \\
\hline 5 & $260 \%$ & 437.8 & $1 / 34\left[2^{\text {nd }}\right]$ & $170 \%$ & 292.2 & $1 / 32\left[2^{\text {nd }}\right]$ & $\begin{array}{l}\text { Cover concrete spalling of } 1 \text { st story column and wall (X-dir.) and significant shear } \\
\text { cracking and cover concrete spalling of } 1 \text { st floor wall (Y-dir.) }\end{array}$ \\
\hline 6 & $130 \%$ & 290.1 & $1 / 45\left[3^{\text {rd }}\right]$ & $100 \%$ & 248.6 & $1 / 33\left[1^{\mathrm{st}}\right]$ & Checked residual seismic capacity by small input magnification \\
\hline 7 & $220 \%$ & 406.7 & $1 / 29\left[2^{\text {nd }}\right]$ & $120 \%$ & 243.1 & $1 / 25\left[1^{\mathrm{st}}\right]$ & Shear failure of 1st story wall in Y-dir. \\
\hline 8 & $220 \%$ & 427.8 & $1 / 25\left[2^{\text {nd }}\right]$ & - & - & - & \\
\hline 9 & $260 \%$ & 444.2 & $1 / 18\left[2^{\text {nd }}\right]$ & - & - & - & Flexural failure of 1st story wall in X-dir. \\
\hline
\end{tabular}

${ }^{*} \mathrm{Q}_{1 \max }$ : Maximum base shear force, ${ }^{* *} \mathrm{R}_{\max }$ : Maximum inter-story drift angle [story where inter-story drift angle is the largest].

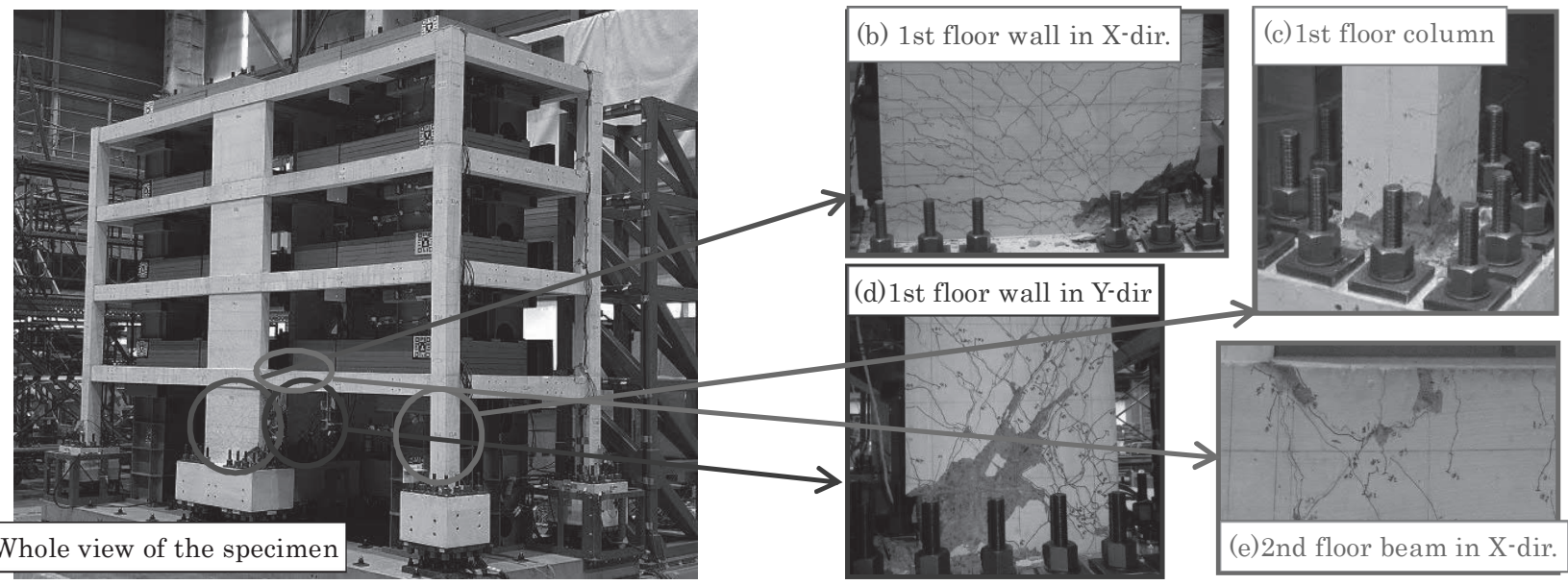

Fig. 8 Damage state of structural members after the final excitation (Run9)
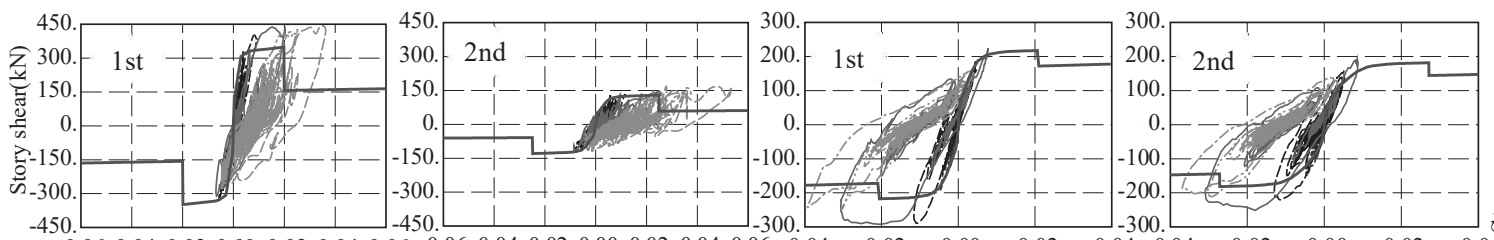

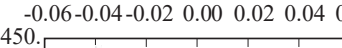
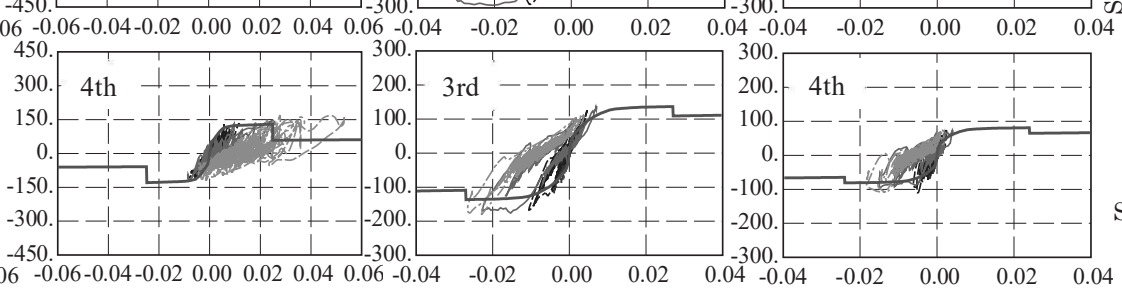

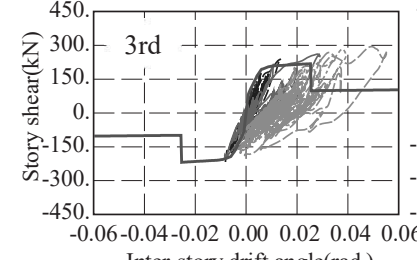

Inter-story drift angle(rad.)

$(\mathrm{a}-1) \mathrm{X}$-direction

$$
\text { Inter-story drift angle(rad.) }
$$

$(\mathrm{a}-2) \mathrm{Y}$-direction

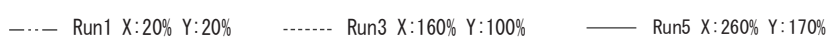

_._- Run2 $X: 80 \% \quad Y: 60 \%$ _- Run4 $X: 240 \% Y: 150 \% \quad \ldots-$ Run6 $X: 130 \%$ Y: $100 \%$

Run7 $X: 220 \%$ Y: $120 \%$
Run8 $X: 220 \%$ Y:0\%

(a) Story shear - inter-story drift angle relationships
}

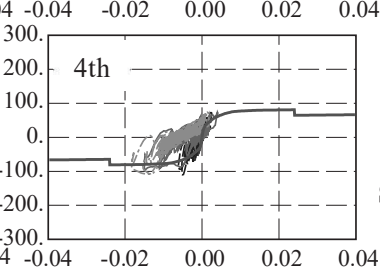

Inter-story drift angle(rad.)

Run9 $X: 260 \%$ Y:0\%

Analysis

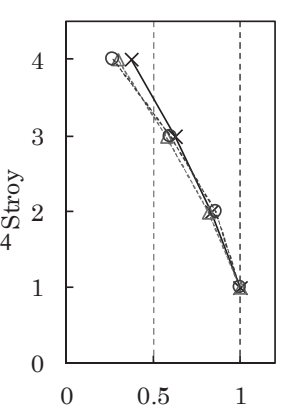

Shear force distribution

$$
\begin{aligned}
& \star \bullet \text { Analysis(Ai) } \\
& \cdots-\triangle-- \text { Test(X-dir.) } \\
& \cdots-\odot-- \text { Test(Y-dir.) }
\end{aligned}
$$

(b) Story shear distribution

Fig. 9 Story shear - inter-story drift angle relationships results and story shear distribution from the shake-table test 


\section{8. 実験結果に基づく架構の破壊形式と安全限界の評価}

\section{1 実験結果に基づく架構の破壊形式と安全限界の評価方法}

実験結果に基づく保有耐震性能指標 $\mathrm{e} \alpha$ の算定方法（下付き文字 「e」は実験值を表す), 及び, 保有耐震性能指標 $\mathrm{e} \alpha$ の值から, 架構 の破壊形式と安全限界を評価する手法を，Fig. 10 及び以下に示す。

（1）壁破壊点及び柱梁破壊点の評価

加振後の損傷観察において, 耐震壁の破壊が初めて確認された（損 傷度 $\mathrm{V}$ に達した）加振を, RunW とする。RunW において, 壁の最 大応答は, 終局変形を既に超えていると考えられ, 壁の実際の破壊 点は，その直前の加振（RunW-1） と RunW の応答の間にあると判 断出来る。同様に, 柱あるいは梁の破壊が初めて確認された際の加 振を RunF とすると, 柱梁の実際の破壊点は, その直前の加振

(RunF-1）とRunF の応答の間にあると言える。

（2）保有耐震性能指標の算定

2 章で説明した定義に倣い, 壁破壊に基づく保有耐震性能指標 $\mathrm{e}$ OW を，壁が終局変形に達寸る以前の加振（Run1～RunW-1）における 最大入力倍率として求める。同様に, 柱梁の破壊に基づく保有耐震 性能指標 $\mathrm{e}_{\mathrm{F}}$ は, RunW Run F-1（壁破壞点以降で柱梁が終局変形 に達する以前の加振) における最大入力倍率として求められる。尚，

Fig. 11 に示すように， edw 及び ${ }_{\mathrm{e}} \mathrm{a}_{\mathrm{F}}$ に該当する加振における壁ある いは柱梁の応答は, 厳密には, 終局変形の手前であるため, 保有耐 震性能指標 ${ }_{\mathrm{e}} \mathrm{AW}_{\mathrm{W}}$ 及び ${ }_{\mathrm{e}} \mathrm{\alpha}_{\mathrm{F}}$ の值は, 実際の值 eact $\mathrm{\alpha W}$, eact $\mathrm{\alpha W}_{\mathrm{W}}$ よりもやや 小さめの值となることに留意されたい。ここで，保有耐震性能指標 の算定において，2 章に示した提案手法（等価線形化法に基づく方 法）では，等価な弾性系における基準地震動と限界地震動のスペク トルの比率として解析值を算定していたため, 基準地震動のスペク トルの大きさを履歴減衰に応じて低減する必要があった。一方，実 験において応答がある点に達した入力倍率（限界地震動の大きさ） は, 履歴減衰の影響を含めた（弾塑性系の）架構の耐震性能を直接 的に表しており，入力倍率そのものが保有耐震性能指標の実験值 $\mathrm{e} \alpha$ に該当する。

（3）架構の破壊形式と安全限界の評価

保有耐震性能指標が, $\mathrm{e} \alpha \mathrm{W}>\mathrm{e}_{\mathrm{e}} \mathrm{a}_{\mathrm{F}}$ の場合, 架構の破壞形式は壁支配型 であり, Run1〜RunW-1の最大入力倍率における応答（edwに対応 する応答) が架構の安全限界点であると判断出来る。 $\mathrm{e} \alpha \mathrm{F}_{\mathrm{e}} \alpha \mathrm{W}$ の場合, 破壊形式は柱梁支配型であり, $\mathrm{e}$ a F に対応する応答が, 架構の安全限 界点であると判断出来る。尚, $\mathrm{e}_{\mathrm{e}} \mathrm{a}_{\mathrm{W}}=\mathrm{e}_{\mathrm{e}} \mathrm{a}_{\mathrm{F}}$ の場合は, 架構の安全限界変 形を小さめ（安全側）に評価出来るよう, edw に対応する応答を安全 限界点として定義する。

\section{2 実験結果に基づく架構の破壊形式と安全限界の評価結果}

8.1 に示した手法に基づいて, 架構の破壊形式及び安全限界を評 価した結果を Fig. 12 に示す。図中では, 各加振の 1 層の層せん断 力最大時刻における応答変位 (代表変位) と加速度を, 実験結果と して示している。また，解析に基づく評価結果（Fig. 6) を合わせて 示している。尚，Run8,9 では Y 方向の入力を行わなかったため, 実験結果の表記を省略している。

(1)壁破壊点及び柱梁破壊点の評価

7 章で記述したように, 縮小 4 層建物の振動台実験では, 壁の変 形性能が（特に X 方向で）事前解析結果よりも大きく, $\mathrm{X}$ 方向は Run9，Y方向はRun7で壁の破壊が確認された。これらの加振は，
(1) Evaluation of wall failure point and column/beam failure point

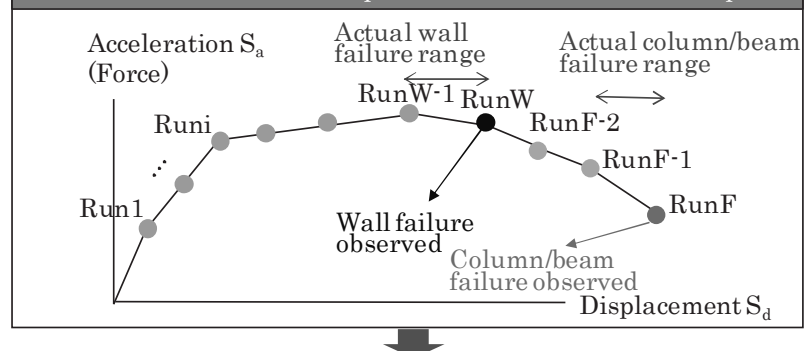

(2) Calculation of SCI (Seismic capacity index)

$\begin{array}{ll}\text { (a)Based on wall failure } & \mathrm{M}_{\mathrm{i}}: \text { Input magnification } \\ \text { SCI }{ }_{\mathrm{e}} \mathrm{a}_{\mathrm{W}}=\max \left(\mathrm{M}_{1}, \mathrm{M}_{2} \ldots, \mathrm{M}_{\mathrm{W}-1}\right) & \text { for Runi }\end{array}$

(b)Based on column/beam failure $\mathrm{Max}$.

SCI ${ }_{e} \alpha_{F}=\max \left(M_{W}, \ldots, M_{\mathrm{F}-2}, M_{\mathrm{F}-1}\right)$

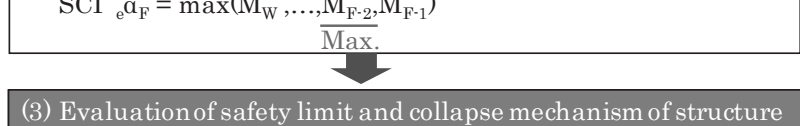

\section{(a) ${ }_{\mathrm{e}} \mathrm{a}_{\mathrm{W}} \geqq{ }_{\mathrm{e}} \mathrm{a}_{\mathrm{F}}$ \\ Safety limit point Response for ${ }_{\mathrm{e}} \mathrm{a}_{\mathrm{W}}$ (RunW-1) \\ Collapse mechanism Dominatedby walls}

(b) ${ }_{e} a_{F}>{ }_{e} a_{W}$

Safety limit point Response for ${ }_{\mathrm{e}} \mathrm{a}_{\mathrm{F}}$ (RunF-2)

Collapse mechanism Dominated by columns and beams

Fig. 10 Evaluation method of safety limit point and collapse mechanism based on the test esults

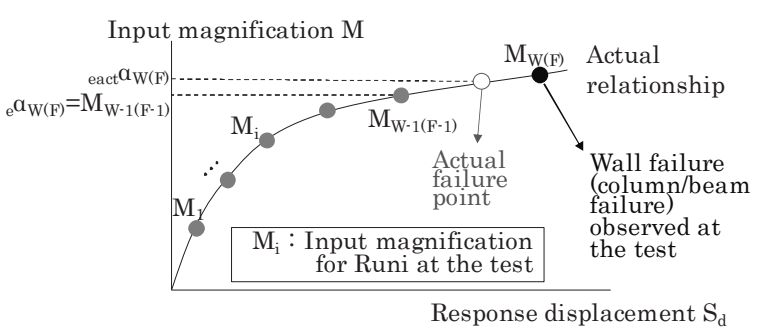

Fig. 11 Seismic capacity index calculated based on the test result $(\mathrm{e} \alpha)$ and actual value $($ eact $\alpha)$

Fig. 10 における RunW に対応すると考えられる。一方，柱梁の破 壊は，最終加振においても確認されなかった。そこで，各方向の最 終加振（Y 方向の Run7 と X 方向の Run9）を，柱梁破壊の直前に 対応する加振（Fig. 10 の RunF-1）とみなすこととした。尚，実際 には，柱梁が破壊に至るまでに，より大きな入力倍率が必要であっ た可能性があり，Run7 及び Run9 を柱梁破壊の直前加振とする仮 定は, 実験結果に基づく保有耐震性能指標の值 $\mathrm{e} \alpha$ をさめに評価し ている可能性があることに留意されたい。

（2）保有耐震性能指標の算定結果

（a）壁破壊に基づく保有耐震性能指標

実験結果における，壁破壞に基づく保有耐震性能指標 $\mathrm{aw}$ は，X方 向で $\mathrm{e}_{\mathrm{W}, \mathrm{X}}=2.60$ (Run5 の入力倍率 $=\operatorname{Run} 1 \sim 8$ の最大入力倍率), $\mathrm{Y}$ 方向で ${ }_{\mathrm{e}} \mathrm{aW}_{\mathrm{W}, \mathrm{Y}}=1.70$ (Run 5 の入力倍率) であり, 事前解析結果 $\mathrm{a}_{\mathrm{W}, \mathrm{X}}$, $\alpha_{W, Y}$ よりもやや大きかった。これは，7 章に示したように，実験結 果における試験体の最大耐力が解析結果よりも大きかったためと考 えられるが，その差は 10～15\%程度であり，耐震壁破壊点において は，解析結果に基づく手法で保有耐震性能指標を概ね精度良く評価 出来ていると言える。

（b）柱梁破壊に基づく保有耐震性能指標

柱梁破壊に基づく保有耐震性能指標は, $\mathrm{X}$ 方向では $\mathrm{e}_{\mathrm{F}, \mathrm{X}}=2.60$ 
(Run9 の入力倍率) であり, 解析值よりも 6 割以上大きい結果と なった。これは, 7 章にも示したように, 解析では, 耐震壁が破壊 点で急激に耐力低下し, 破壊点以降の残存耐力 $=0$ となるという想定 をしているが, 実験においては, 曲げ破壊した耐震壁の変形能力（耐 力が大きく低下し始める変形) が解析の想定よりも高く, 破壊後も 残存耐力を有していたためと考えられる。一方, $\mathrm{Y}$ 方向では, ${ }_{\mathrm{e}} \mathrm{\alpha}_{\mathrm{F}, \mathrm{Y}}=1.20$ (Run7 の入力倍率) と, 解析值 $\mathrm{\alpha}_{\mathrm{F}, \mathrm{Y}}$ よりも $30 \%$ 程度小さ い結果となり，提案手法が危険側の評価を与える結果となった。こ こで, Table 6 から分かるように, 保有耐震性能指標 $\alpha_{F, Y,}$ edF,Y 算定 点おける耐力 (応答加速度 $S_{a}$ ) は, 実験值が解析值を上回っている。 また, 変形 (応答変位 $\mathrm{S}_{\mathrm{d}}$ ) は, 実験值が解析值を 1 割程度下回って いるが大きな差はみられない。即ち, 提案手法で用いている解析モ デルにおける各部材の耐力や終局変形の值は, 危険側の評価を与え る大きな要因にはなっていない。一方, 減衰定数は, 実験值が解析 值を 2 割程度下回っている。ここで, 減衰定数の解析值 $\mathrm{h}$ は(2)式で 算定し, 実験值は文献 15) に示される平均等価減衰定数 $\mathrm{h}_{\mathrm{s}}$ を用いた。 $\mathrm{h}_{\mathrm{s}}$ は, 各層の層せん断力一層間変形角関係を動的縮約 ${ }^{16)}$ した等価 1 自由度系の応答に基づき，(4)式で求められる。

$$
h_{s}=-\int_{0}^{T} \ddot{y}_{0}(t) \dot{y}(t) d t /\left(2 \omega_{e} \int_{0}^{T} \dot{y}(t)^{2} d t\right)
$$

$\mathrm{T}$ : 加振波の継続時間, $\ddot{y_{0}}(\mathrm{t})$ : 時刻 $\mathrm{t} の 1$ 階の加速度, $\dot{\mathrm{y}}(\mathrm{t}):$ 時刻 $\mathrm{t}$ の等価 1 自由度系の応答速度, $\omega_{\mathrm{e}}$ : 正負の最大応答点（応答変位 最大点）を結しで算定した等価剛性から計算した等価固有角振動数

ここで, 各 Run における平均等価減衰定数 $\mathrm{h}_{\mathrm{s}}$ の推移（Fig. 13） を見ると, Run3 以降では值が減少傾向にあり, 振動実験による繰 り返し加振で発生する損傷によってエネルギー吸収性能 (履歴減衰) が低下したと考えられる。また, 単調載荷の荷重増分解析を用いて いるため, 解析においては残留変位の影響は考慮されないが, 実験 においては, Run6の終了時に大きな残留変位 $(86 \mathrm{~mm})$ が生じてお り, 実質的な変形性能 (Run7 の加振開始時〜最大応答時までの変 形量）は, Table 6 に示した $\mathrm{S}_{\mathrm{d}}$ の値 $(282 \mathrm{~mm})$ よりも小さかったと 考えられる。残留変位 $\mathrm{S}_{\mathrm{dr}}$ (Run6 終了時) を考慮して実質的な変形 性能 $\mathrm{S}_{\mathrm{ds}}$ を(5)式で計算した場合, $\mathrm{S}_{\mathrm{ds}}=196 \mathrm{~mm}$ となり, 解析值 (319mm) を大きく下回る結果となった（Table 6)。

$$
\mathrm{S}_{\mathrm{ds}}=\mathrm{S}_{\mathrm{d}}-\mathrm{S}_{\mathrm{dr}}
$$

以上の結果を踏まえ, 最終加振以前の損傷に着目すると, Fig. 14 に示すように，実験においては，Run6 の終了時において，柱梁に も損傷度IIII IVの大きな損傷が生じていることがわかる。しかしな がら，解析值 $\alpha_{F, Y}$ の計算で用いた建物モデル（Fig. 4(b)のモデル） では, 解析の初期設定として, 壁脚の損傷の夕を考慮しており, 柱 梁は無損傷状態であると仮定している。即ち, 実験において生じて いた振動実験における繰り返し加振（各 Run）で発生する柱梁の累 積損傷による性能低下 (エネルギー吸収性能の低下, 残留変位の発 生による実質的な変形性能の低下）を, 解析では考虑出来ていない ため, 柱梁破壊に基づく保有耐震性能指標 $\alpha_{F, Y}$ を過大評価する結果 になったと考えられる。

\section{（3）架構の破壊形式と安全限界の評価結果}

実験においては, $\mathrm{X}$ 方向, $\mathrm{Y}$ 方向共に, $\mathrm{e}_{\mathrm{WW}} \mathrm{e}_{\mathrm{e}} \mathrm{\alpha}_{\mathrm{F}}$ であり, 試験体 は壁支配型の架構であったと言える。また, 架構の安全限界点は, $\mathrm{X}$ 方向, $\mathrm{Y}$ 方向共に, Run5（壁破壊以前の最大入力）における最大
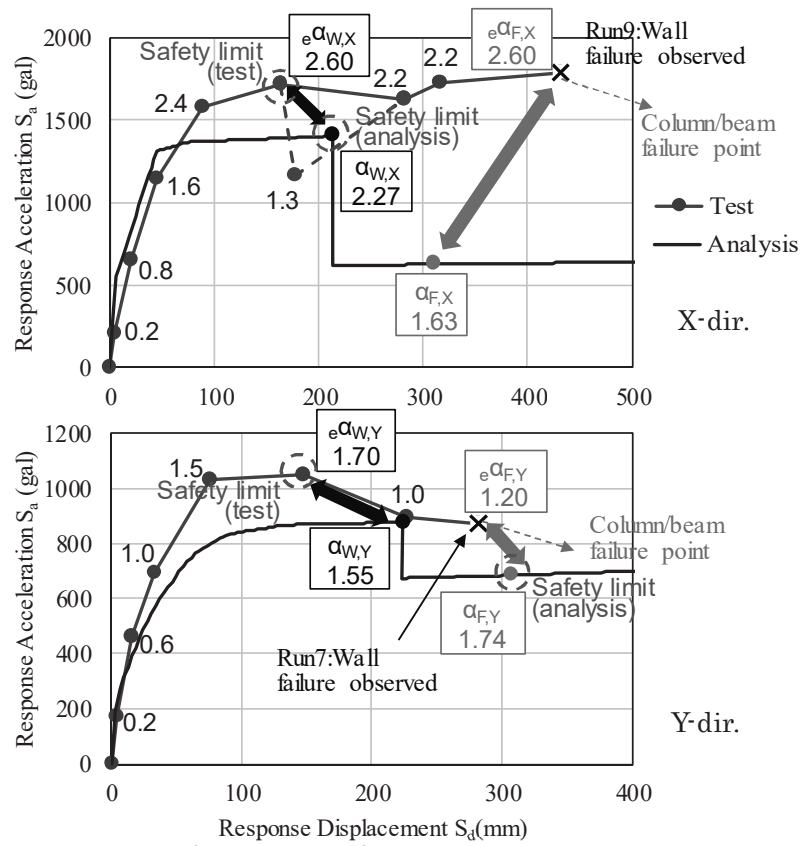

Fig. 12 Results of evaluation of structure collapse mechanism and safety limit point based on the test results

Table 6 Response acceleration,

displacement and damping at the evaluation points of Seismic capacity index based on column/beam failure

\begin{tabular}{|c|c|c|c|c|}
\hline & $\mathrm{S}_{\mathrm{a}}(\mathrm{gal})$ & $\mathrm{Sd}(\mathrm{mm})$ & $\mathrm{S}_{\mathrm{ds}}(\mathrm{mm})$ & $\mathrm{h}, \mathrm{h}_{\mathrm{s}}$ \\
\hline \hline Analysis & 684 & 319 & 319 & 0.193 \\
\hline $\begin{array}{c}\text { Test } \\
\text { (Run7) }\end{array}$ & 871 & 282 & 196 & 0.160 \\
\hline
\end{tabular}

$\mathrm{S}_{\mathrm{a}}:$ Response acceleration

$\mathrm{S}_{\mathrm{d}}$ : Response displacement

$\mathrm{S}_{\mathrm{dr}}$ : Response displacement considering residual displacement $\left(\mathrm{S}_{\mathrm{ds}}=\mathrm{S}_{\mathrm{d}}-\mathrm{S}_{\mathrm{dr}}\right)$ $\mathrm{S}_{\mathrm{dr}}$ : Residual displacement $\mathrm{h}, \mathrm{h}_{\mathrm{s}}$ : Damping factor

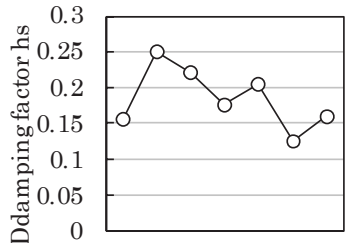

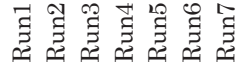

Fig. 13 Average equivalent damping factor in the test results (Y-dir.)

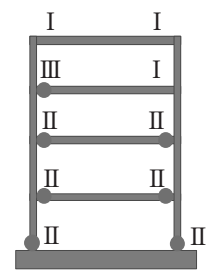

(Y1) (Y2) (Y1)

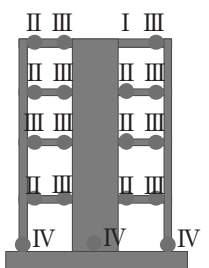

(Y2) Y1

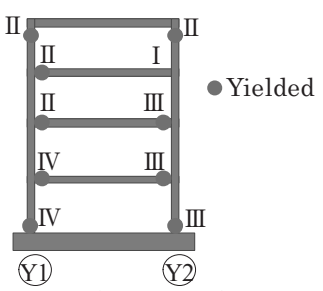

(Y2)
Fig. 14 Visually evaluated damage level of members after Run6

応答点であると判断出来る。X方向では破壊形式及び安全限界点が, 解析に基づく評価と一致する結果となったが，Y方向では解析と異 なる結果となった。また，X方向においても，edw, $={ }_{\mathrm{e}} \alpha \mathrm{F}, \mathrm{X}$ であること から, 解析結果の想定と比べて破壊形式が明確には現れなかったと いえる。尚，この評価結果は，入力倍率の設定や加振順序によって 影響を受ける可能性があり, その点については留意する必要がある。 以上に示したように，Y 方向においては，提案手法（解析に基づ く評価）では，架構の破壊形式を適切に評価出来ず，安全限界変形 を過大評価する（危険側に評価する）結果となった。この要因とし て，実験においては柱梁が破壊には至らなかったために最終加振 (Run7) を柱梁破壊の直前加振と仮定していること，X方向加振に よる損傷で $\mathrm{Y}$ 方向の性能が低下していること等も考えられるが，本 
報では, まず，前述した柱梁の累積損傷の影響に着目することとし た。次章では, 提案手法を改良し, 柱梁の累積損傷を考慮した上で, $\mathrm{Y}$ 方向における柱梁破壞点の保有耐震性能指標, 並びに, 架構の破 壊形式と安全限界の再評価を行う。

\section{9. 柱梁の累積損傷を考慮した架構の破壊形式と安全限界評価}

\section{1 被災度区分判定基準における耐震性能残存率 $\mathrm{R}$ の算定法}

被災度区分判定基準 1)では，被害調查時に記録した部材損傷度に 応じて Table 7 のように与えられる各ヒンジ位置発生位置の耐震性 能低減係数 $\eta_{\mathrm{i}}$ と曲げ強度 $\mathrm{M}_{\mathrm{ui}}$ から, (6) 式で建物の耐震性能残存率 $\mathrm{R}$ （被災後耐震性能／被災前耐震性能）を算定している。而震性能低 減係数 $\mathrm{\eta}$ は損傷による部材の耐震性能（耐力, 変形性能, エネルギ 一吸収性能（減衰））の低下を総合的に表した指標である。

$$
\mathrm{R}=\Sigma\left(\eta_{\mathrm{i}} \mathrm{M}_{\mathrm{ui}}\right) / \Sigma \mathrm{M}_{\mathrm{ui}}
$$

\section{2 柱梁の累積損傷を考慮した保有耐震性能指標の算定方法}

実験においては，8 章に示したように，Run7を Y 方向の柱梁破 壊の直前加振とみなし, Run7 における入力倍率（1.20）を, 柱梁破 壞に基づく保有耐震性能指標 $\mathrm{ed}_{\mathrm{F}, \mathrm{Y}}$ としていた。ここで, Fig. 14 に 示したように, 地震前 (Run7 の加振前) において, 柱梁は比較的大 きな損傷を受けていた。一方, 提案手法では, 壁脚をピンとした解 析モデル（耐震壁破壊後モデル, Fig.4(b)) を用いて, 柱梁破壊点の 保有耐震性能指標を算定していた。即ち, 地震（柱梁が破壞に至る 地震, 以下当該地震) の発生前の状態として, 柱梁は無損傷である と仮定しており, 実験時の状態との間に差異が生じていたと言える。 8 章に示したように, 当該地震以前の地震における柱梁の累積損傷 による性能低下は，エネルギー吸収性能（減衰）や变形性能の低下 に起因すると考えられ，厳密には，各々の影響を適切に評価するこ とが望ましいが, 本報では, 簡略的な手法として, 9.1 に示した文献 1)の考え（倸数 $\eta$ に基づいて架構の耐震性能の低下（耐震性能残存 率 R）を総合的に評価する考え）を活用し，柱梁の累積損傷を考慮 した保有耐震性能指標の評価法を提案する。評価法を以下に示す。

(6)式に倣い, 柱梁の各ヒンジ発生位置における耐震性能低減係数 ${ }_{\mathrm{f}} \eta_{\mathrm{i}}$ と曲げ強度 $\mathrm{f} \mathrm{M}_{\mathrm{ui}}$ から, 柱梁部分の耐震性能残存率 $\mathrm{R}_{\mathrm{F}}$ を(7)式で求 める。

$$
\mathrm{R}_{\mathrm{F}}=\Sigma\left({ }_{\mathrm{f}} \eta_{\mathrm{i}} \mathrm{M}_{\mathrm{ui}}\right) / \Sigma_{\mathrm{f}} \mathrm{M}_{\mathrm{ui}}
$$

耐震性能低減係数 $\mathrm{f} \eta_{\mathrm{i}}$ は, 各加振終了後に目視判定した, 柱梁の七 ンジ発生位置（1 階柱脚と各階梁端）における部材損傷度に基づい

て, Table 7 に従って求める。

耐震壁破壊後モデルにおける柱梁破壊点の保有耐震性能指標 $\alpha_{\mathrm{F}, \mathrm{Y}}$ に, 柱梁の累積損傷を考慮するための係数 $\mathrm{R}_{\mathrm{F}}$ を乗じ, 柱梁破壊点に おける累積損傷を考慮した保有耐震性能指標 $\alpha_{F, Y}{ }^{\prime}$ を，(8)式で求める。

$$
\alpha_{\mathrm{F}, \mathrm{Y}}{ }^{\prime}=\mathrm{R}_{\mathrm{F}} \times \alpha_{\mathrm{F}, \mathrm{Y}}
$$

\section{3 柱梁の累積損傷を考慮した保有耐震性能指標の算定結果}

(7)式を用いて, 各加振後における柱梁部分の耐震性能残存率 $R_{F}$ を算定した結果を Fig. 15 に示寸。尚, X3 通り最上階の柱は, 梁よ りも損傷度が大きかったため, 柱の損傷度を梁の損傷度に読み替え て耐震性能残存率 $R_{\mathrm{F}}$ を求めた。 $R_{\mathrm{F}}$ は, Run4 以降低下し始め, Run6 終了後においては, $\mathrm{R}_{\mathrm{F}}=60 \%$ となっている。(8)式を用いて, 柱梁破 懐点における保有耐震性能指標架 $\alpha_{\mathrm{F}, \mathrm{Y}}{ }^{\prime}$ 算定寸ると, $\alpha_{\mathrm{F}, \mathrm{Y}^{\prime}}=0.60 \times$ $1.74=1.05$ となり, 実験值 $\mathrm{e}_{\mathrm{e}} \mathrm{F}, \mathrm{Y}=1.20$ と概水一致する結果となった。
Table 7 Seismic performance deterioration factor for flexural columns and beams

\begin{tabular}{|c|c|}
\hline $\begin{array}{c}\text { Damage } \\
\text { level }\end{array}$ & $\begin{array}{c}\text { Seismic performance } \\
\text { deterioration factor } \mathrm{n}\end{array}$ \\
\hline \hline 0 & 1.0 \\
\hline $\mathrm{I}$ & 0.95 \\
\hline $\mathrm{II}$ & 0.75 \\
\hline $\mathrm{III}$ & 0.5 \\
\hline $\mathrm{IV}$ & 0.2 \\
\hline $\mathrm{V}$ & 0 \\
\hline
\end{tabular}

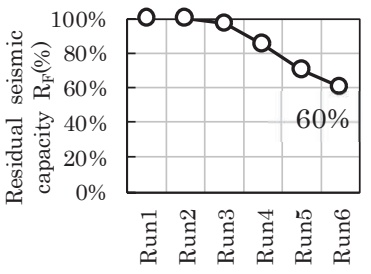

Fig. 15 Residual seismic capacity of columns and beams (Y-dir.)

\section{4 柱梁の累積損傷を考慮した架構の破壊形式と安全限界評価結果}

9.3 で求めた柱梁破壊点における保有耐震性能指標 $\alpha_{\mathrm{F}, \mathrm{Y}}{ }^{\prime}$ （柱梁の 累積損傷を考慮した值）を用いて，Y 方向における架構の破壊形式 を再評価したところ， $\mathrm{a}_{\mathrm{W}, \mathrm{Y}} \geqq \mathrm{\alpha}_{\mathrm{F}, \mathrm{Y}}$ であり，壁支配型となった。また， 架構の安全限界点は, 壁破壊点となり, 実験結果に一致した。以上 の結果から，柱梁の累積損傷を考慮すれば，提案手法に基づいて架 構の破壊形式と安全限界を適切に評価出来ることが示された。

尚，本検討では，解析結果と実験結果の差異の要因を検討するた め, 耐震性能残存率 $\mathrm{R}_{\mathrm{F}}$ を, 実験時の損傷観察結果に基づいて定めた が，今後，実建物における評価を行うに当たっては，柱梁が破壊に 至る地震（当該地震）の前の状態における，各部材の損傷度（ある いは耐震性能低減係数 n）を推定する手法の開発が必要となる。ま た，本報では，実験の加振経過に合わせ，Run6 終了時を地震前の 状態として想定したが，Fig. 15 からもわかるように，想定する架構 の損傷状態に応じて, 耐震性能残存率 $R_{\mathrm{F}}$ 並びに保有耐震性能指標 $\alpha_{\mathrm{F}, \mathrm{Y}}$ の值は大きく変わるため, 注意が必要である。また, 架構の破壊 形式と安全限界をより正確に評価するため, 本実験の X方向で見ら れたような，曲げ破壊型の耐震壁の残存耐力の影響を評価すること も必要であると考えられる。

\section{0. まとめ}

$\mathrm{RC}$ 造建物における架構の破壊形式と安全限界の評価を目的とし て，連層耐震壁を有する $\mathrm{RC}$ 造 4 層建物縮小試験体の振動台実験を 行った。本研究により得られた知見を以下に示す。

(1)試験体は曲げ降伏型の全体崩壊形とし，1階の柱と壁の脚部及び 各階の梁端にヒンジを生じる計画とした。X方向は, 壁破壊点の保 有耐震性能指標 $\alpha_{W}>$ 柱梁破壊点の保有耐震性能指標 $\alpha_{\mathrm{F}}$ であり, 壁 の破壊点が架構全体の安全限界となるような壁支配的型の架構, $\mathrm{Y}$ 方向は， $\alpha_{\mathrm{F}}>\alpha_{\mathrm{W}}$ であり，柱梁の破壞点が架構の安全限界となる柱梁 支配型の架構とすることを設計方針とした。

(2)実験においては，設計の想定通り，X方向と Y 方向の両方におい て, 1 階の柱と壁の脚部及び各階の梁端に降伏ヒンジが発生したが, Y 方向では設計の想定と異なり, 1 階の壁が最終的にせん断破壞し た。X方向では, 最終的に 1 階の壁が曲げ破壊した。架構の最大耐 力と変形性能は, $\mathrm{X}$ 方向と $\mathrm{Y}$ 方向共に, 解析結果よりも大きかった。 （3）各加振後に確認した部材損傷度と加振波の入力倍率に基づいて, 壁破壊及び柱梁破壊に基づく保有耐震性能指標の実験值 ${ }_{\mathrm{e}} \alpha_{\mathrm{W}}, \mathrm{e}_{\mathrm{F}}$ を 算出した結果， $\mathrm{e} \alpha_{\mathrm{W}}$ は解析值（筆者らの提案手法による評価結果）と 概ね一致した。一方， $\mathrm{e} \alpha_{\mathrm{F}}$ は X 方向では解析值よりも 6 割程度大き く, $\mathrm{Y}$ 方向では解析值よりも 3 割程度小さい結果となった。この原 因は，曲げ壁の残存耐力が解析の想定よりも大きかったこと（X 方 
向）や, 複数回の加振による柱梁の累積損傷によって, 壁破壞後の 架構の耐震性能が低下したこと（Y方向）であると推察された。

（4）保有而震性能指標 ${ }_{\mathrm{e}} \alpha_{\mathrm{W}}, \mathrm{e} \alpha_{\mathrm{F}}$ に基づいて架構の破壊形式と安全限界 を評価した結果, X方向では, 破壊形式は壁支配的型で壁破壊点が 安全限界となり, 解析に基づく評価結果と一致したが, Y方向では, 架構の破壊形式は壁支配型であり, 壁破壊点が安全限界となる評価 結果となった。これは, 解析に基づく評価とは異なる結果であり, その原因として，(3)に示した柱梁の累積損傷の影響が考えられる。 （5）Y方向において, 提案手法（解析に基づく評価手法）を改良し, 柱梁の累積損傷を考慮して, 架構の破壊形式と安全限界の再評価を 行ったところ, 実験結果と一致し, 提案手法の有効性が示された。

\section{謝辞}

本研究は, 東北大学と大林組の共同研究として実施したものです。 また, 本研究の一部は, JST 産学共創プラットフォーム共同研究推 進プログラム・大規模都市建築における日常から災害時まで安心し て社会活動が継続できる技術の創出（領域代表者：吉敷祥一 東京工 業大学准教授, 課題番号 JPMJOP1723）の支援を受けました。

\section{参考文献}

1) Japan Building Disaster Prevention Association: Standard for Postearthquake Damage Level Classification of Buildings, 2016.3 (in Japanese)

日本建築防災協会：震災建築物の被災度区分判定基準及び復旧技術指針, 2016.3

2) Maeda, M. and Miura, K.: Post-Earthquake Damage Evaluation for Reinforced Concrete Buildings with Various Collapse Mechanism, 15th World Conference on Earthquake Engineering, 2012.9

3) Matsukawa, K. and Maeda, M.: Practical Collapse Assessment for Reinforced Concrete Structures Based on Seismic Response Spectrum, Tenth U.S. National Conference on Earthquake Engineering, 2014.7

4) Fujita, K., Maeda, M. et al.: Residual Seismic Capacity Evaluation for RC Frames with Multi-story Flexural Wall, Proceedings of Japan Concrete Institute, Vol.41, No.2, pp.799-804, 2019.7 (in Japanese) 藤田起章, 前田匡樹ほか:曲げ破壞型連層耐震壁を有する $\mathrm{RC}$ 造架構造の残 存耐震性能評価, コンクリート工学年次論文集 Vol.41, No.2, pp.799-804, 2019.7

5) Katsumata, H., Shirai, K. et al.: Shaking Table Test of R/C 4 Story Shear Wall Frame Model with Multi Directional Input Motion (Part 1-2), Summary of Technical Papers of Annual Meeting, Architectural Institute of Japan, Structures-IV, pp.407-410, 2005.7 (in Japanese) 勝俣英雄, 白井和貴ほか: 鉄筋コンクリート造 4 層壁フレーム模型の多方 向入力振動台実験 (その 1-2), 日本建築学会大会学術講演梗概集, 構造-IV, pp.407-410, 2005.7

6) Matsumori, T., Shirai, K. and Kabeyasawa, T.: Study on Seismic Performance of R/C Wall-frame Structures Based on Large-scale Shaking Table Test, Journal of Structural and Construction Engineering (Transactions of AIJ), Vol.73, No.614, pp.85-90, 2007.4 (in Japanese) 松森泰造，白井和貴，壁谷澤寿海：大型振動台による鉄筋コンクリート而 震壁フレーム構造の耐震性に関する研究, 日本建築学会構造系論文集, Vol.73, No.614, pp.85-90, 2007.4

7) Sugimoto, K, Katsumata, H. et al.: Shaking Table Test of 6-Story Wall Frame Building to Investigate Collapse Process of RC Buildings, 17th World Conference on Earthquake Engineering, 2017.1

8) Architectural Institute of Japan (2004), Guidelines for Performance Evaluation of Earthquake Resistant Reinforced Concrete Buildings (Draft), (in Japanese)

日本建築学会：鉄筋コンクリート造建物の耐震性能評価指針 (案) ・同解説, 2004.7

9) Miura, K., Maeda, M. et al.: Evaluation Method of Contribution Factor of Structural Member for Seismic Capacity of Single-story RC frames Considering Strength and Energy Dissipation, Journal of Structural and Construction Engineering (Transactions of AIJ), Vol.77, No.678, pp.1283-1290, 2012.8 (in Japanese)

三浦耕太, 前田匡樹ほか: 部材耐力と減衰を考慮した RC 造 1 層架構の耐 震性能に及ぼす各部位の影響度評価法,日本建築学会構造系論文集, Vol.77, No.678, pp.1283-1290, 2012.8

10) Matsukawa, K. and Maeda, M.: Methodology to Evaluate the Collapse Limit State of R/C Frames Based on the Seismic Response Spectrum, Japan Architectural Review, Vol.1, No.4, pp.432-442, 2018.10

11) Hao, L., Jin, K. and Maeda, M.: Residual Seismic Capacity Evaluation for Damaged RC Buildings with Mixed Failure Mode Considering Reduction of Seismic Performance, Proceedings of Japan Concrete Institute, Vol.39, No.2, pp.721-726, 2017.7 (in Japanese)

Hao Linfei, 晋沂雄, 前田匡樹: 破壞モード混在型被災 RC 造架構における 構造性能低下を考慮した残存耐震性能評価法, コンクリート工学年次論文 集 Vol.39, No.2, pp.721-726, 2017.7

12)Information Center for Building Administration: Technological Related to Structures of Buildings, 2015.6 (in Japanese) 建築行政情報センター: 2015 年版建築物の構造関係技術基準解説書, 2015.6

13) Architectural Institute of Japan, Design Guidelines for Earthquake Resistant Reinforced Concrete Buildings Based on Inelastic Displacement Concept, Japan,1999.9 (in Japanese)

日本建築学会：鉄筋コンクリート造建物の勒性保証型耐震設計指針・同解 説, 1999.9

14) Building Research Institute: Investigation on Structural Performance Evaluation of RC Members using Comprehensive Experimental Database, 2016.11 (in Japanese)

建築研究所：実験データベースを用いた鉄筋コンクリート造部材の構造特 性評価式の検証, 2016.11

15) Shibata, A.: Dynamic Analysis of Earthquake Resistant Structures, 2010.4

16) Kuramoto, H.: Earthquake Response Characteristics of Equivalent SDOF System Reduced from Multi-story Buildings and Prediction of Higher Mode Responses, Journal of Structural and Construction Engineering (Transactions of AIJ), No.580, pp.61-68, 2004.6 (in Japanese)

倉本洋：多層建築物における等価 1 自由度系の地震応答特性と高次モード 応答の予測, 日本建築学会構造系論文集, No.580, pp.61-68, 2004.6 


\author{
Kota MIURA ${ }^{* 1}$, Kisho FUJITA *2, Yu TABATA*3, \\ Masaki MAEDA ${ }^{* 4}$, Alex SHEGAY*5 and Kenji YONEZAWA*6 \\ ${ }^{* 1}$ Researcher, Technical Research Institute, Obayashi Corporation, M.Eng. \\ ${ }^{* 2}$ Grad. Student, Graduate School of Eng., Tohoku Univ. \\ *3 KUME SEKKEI Co., Ltd., M.Eng. (Former Grad. Student, Graduate School of Eng., Tohoku Univ.) \\ *4 Prof., Graduate School of Eng., Tohoku Univ., Ph.D. \\ ${ }^{* 5}$ Research Fellow, Graduate School of Eng., Tohoku Univ., Ph.D. \\ ${ }^{* 6}$ Senior Engineer, Technical Research Institute, Obayashi Corporation, Ph.D.
}

After an earthquake, it is important to judge the safety of buildings and make an efficient recovery plan. For that, it is necessary to know quantitatively the damage level and safety limit of buildings. An evaluation method of residual seismic capacity is described in the Japanese Standard for Post-earthquake Damage Level Classification of Buildings; however, the method does not consider the difference of deformation capacity of members such as walls and frames (columns and beams). Even though evaluation methods were proposed in previous research for the damage level and safety limit of RC buildings, the focus of the method has been mainly for moment-resting frames. Moreover, not enough experimental investigation has been done to verify the application of these methods. In this research, a new evaluation method for the collapse mechanism and safety limit of dual structures, which have members with different deformation capacity, was proposed. A shake-table test has been carried out to investigate the applicability of the proposed method to RC buildings consisting of moment resisting frames and shear walls.

The test specimen was a $1 / 4$ scale model of a 4-story RC building with multi-story shear walls in both $\mathrm{X}^{-}$and $\mathrm{Y}^{-}$ directions. The structure was designed to exhibit a total collapse mechanism (frame-sway mechanism) and so, plastic hinges were designed at the bottom of columns and walls in the first story and beam ends of each story. To investigate the difference of collapse mechanism in the $\mathrm{X}^{-}$and Y-directions, contribution ratio of shear wall to the whole seismic capacity was varied. In the X-direction, two shear walls were placed with the intention of making the failure of shear walls dominate the collapse mechanism of the whole structure (i.e., the failure point of walls corresponded to the global structural safety limit). In the Y-direction, only one shear wall was used such that failure of columns and beams would dominate the global collapse mechanism, which meant that failure of the wall would not correspond to the global structural safety limit. The design concept was quantitatively confirmed based on seismic capacity indices using results of nonlinear pushover analyses.

In the shake-table test, scaled artificial ground motions compatible with the Japanese standard spectrum were used as input. The damage of walls preceded in both directions and at the end of the test, the walls were severely damaged and the whole structure was close to collapse. The strength and the deformation capacity of the structure were higher than predicted by the analysis. Finally, the collapse mechanism and the safety limit of the specimen was evaluated. As a result, the collapse mechanism of the X-direction frame was wall-dominant and the wall failure point corresponded to the safety limit, consistent with the results obtained from analyses before the test. In the Y-direction, the collapse mechanism was also wall-dominant, even though a frame-dominant response was anticipated. It was estimated that the accumulated damage of columns and beams by former shakings degraded their seismic capacity after the wall collapse, which was not considered in the proposed analytical evaluation method, and so, the proposed method was improved considering the effect of accumulated damages of members simply. As a result, the collapse mechanism and safety limit reevaluated by the method was consistent with the test result and the applicability of the method was proved. 